\title{
Mononuclear Cell Adherence Induces Neutrophil Chemotactic Factor/Interleukin-8 Gene Expression
}

\author{
Keita Kasahara, Robert M. Strieter, Stephen W. Chensue, Theodore J. Standiford, \\ and Steven L. Kunkel \\ Departments of Pathology (K.K., S.W.C., S.L.K.) and Internal Medicine (R.M.S., T.J.S.), Division of Pulmonary and Critical Care \\ Medicine, The University of Michigan Medical School, Ann Arbor
}

\begin{abstract}
The accumulation of polymorphonuclear cells (PMN) in tissue is an essential element of the inflammatory response that is important in host defense. Adherence to endothelium constitutes the first step in PMN migration from the vascular compartment to the interstitium. We demonstrate that human peripheral blood mononuclear cells (PBMC) adherent to plastic can result in expression of interleukin-8 (IL-8), a potent PMN chemoattractant and activating cytokine. Northern blot analyses showed PBMC adherent to plastic expressed IL-8 steady-state mRNA levels by $30 \mathrm{~min}$, peaked at $8 \mathrm{~h}$, and then decreased over the next $16 \mathrm{~h}$. In contrast, nonadherent PBMC (cultured in teflon chambers) expressed less than $25 \%$ of the maximal IL-8 steady-state mRNA levels as compared with adherent PBMC. Adherent PBMC-associated IL-8 determined by immunohistochemistry, supernatant chemotactic bioactivity, and extracellular antigenic IL-8 paralleled IL-8 mRNA expression. Antigenic and bioactive IL-8 were significantly apparent by $4-8 \mathrm{~h}$, respectively, and increased significantly to maximal levels by $24 \mathrm{~h}$. Furthermore, adherent PBMC IL-8 gene expression was suppressed by either concomitant treatment with actinomycin-D or cycloheximide, yet specific neutralizing antibodies directed against either IL-1 $\beta$ or tumor necrosis factor (TNF)- $\alpha$ failed to alter adherence-induced steady-state IL-8 mRNA levels. These data support the hypothesis that PBMC adherence is an important signal for the production of IL-8, and may be essential to the development of the inflammatory response through the elicitation of PMN.
\end{abstract}

Key words: polymorphonuclear cells, peripheral blood mononuclear cells, inflammatory response

\section{INTRODUCTION}

Adherence of inflammatory cells to the microvascular endothelium represents the initial step in the elicitation of these cells to sites of inflammation $[2,5,6,9,13,23]$. Directed cellular migration is first dependent upon adherence followed by diapedesis. Previous investigations have shown that adherence of peripheral blood mononuclear cells (PBMC) to plastic, plastic coated with matrix, or endothelial cells is a significant stimulus for the induction of steady-state levels of interleukin-1 (IL-1 $\alpha$ and IL-1 $\beta$ ), tumor necrosis factor (TNF- $\alpha$ ), and colony stimulating factor-1 (CSF-1) mRNA $[4,8,15]$. Although these inflammatory cytokines may influence the accumulation of polymorphonuclear cells (PMN) to sites of inflammation, neither IL-1, TNF, nor CSF-1 induces a direct chemotactic influence on PMN $[11,14,26]$. A number of PMN chemotactic factors have been identified, including LTB4 $[7,16]$, platelet activating factor (PAF) [7,12], C5a [7,12], platelet-derived growth factor $[12,17]$, and fibronectin [12]. These factors, however, are indiscriminate in their recruitment of immune cells as they are chemotactic for both PMN and mononuclear cells. Recently several studies have reported a novel neutrophil chemotactic and activating polypeptide, interleukin-8 (IL-8) derived from a number of immune and nonimmune cells $[1,11,14,26]$.

In this study we demonstrated by Northern blot analysis, immunohistochemical localization, IL-8 ELISA, and PMN chemotactic bioactivity that PBMC adherent to plastic express IL-8 mRNA, antigen, and bioactivity in a time-dependent fashion. Furthermore, this IL-8 generation reflected de novo production and was dependent

Abbreviations used: IL-1, interleukin 1; TNF, tumor necrosis factor; CSF-1, colony stimulating factor-1; IL-8, interleukin 8; DMSO, dimethyl sulfoxide; PDGF, platelet-derived growth factor; PAF, platelet activating factor; PBMC, peripheral blood mononuclear cells; PMN, polymorphonuclear cells; DEPC, diethyl pyrocarbonate; PBS, phosphate buffered saline; HBSS, Hank's balanced salt solution; ELISA, enzyme-linked immunosorbent assay; BSA, bovine serum albumin; MDNCF, monocyte-derived neutrophil chemotactic factor; NAP-1, neutrophil attractant/activating peptide-1.

Received October 22, 1990; accepted January 22, 1991.

Reprint requests: Steven L. Kunkel, Department of Pathology, Box 0602, 1301 Catherine Rd., The University of Michigan Medical School, Ann Arbor, MI 48109-0602. 
upon a protein intermediate that was neither IL-1 nor TNF. Therefore, mononuclear phagocytic cell adherence may play an important role in regulating the production of IL-8 and development of inflammation.

\section{MATERIALS AND METHODS Reagents}

Murine antihuman monoclonal IL-1 $\beta$ antibodies were the generous gift of the Upjohn Co. (Kalamazoo, MI), with $1 \mu \mathrm{g}$ capable of inhibiting $95 \%$ of the IL-1 $\beta$ induced production of IL-2 by $1 \mathrm{~A} 5$ murine $\mathrm{T}$ cells. Human recombinant IL-8 was the generous gift of Sandoz Pharmaceutical (Hanover, NJ). Polyclonal antihuman TNF or IL-8 antisera were produced by immunization of rabbits with recombinant TNF or IL-8 in multiple intradermal sites with complete Freund's adjuvant. Polyclonal TNF and IL-8 antisera used in this study were capable of neutralizing $0.5 \mathrm{ng}$ of human recombinant TNF at a dilution of $1: 25,625$ and $10 \mathrm{ng}$ of human recombinant IL-8 at a dilution of 1:1,000, respectively [22]. Stock cycloheximide (Sigma, St. Louis, MO) was prepared at a concentration of $10 \mathrm{mg} / \mathrm{ml}$ in sterile RPMI1640 (Whitaker Biomedical Products, Whitaker, CA), $1 \mathrm{mM}$ glutamine, $25 \mathrm{mM}$ HEPES, $100 \mathrm{U} / \mathrm{ml}$ penicillin, and $100 \mathrm{ng} / \mathrm{ml}$ streptomycin (Hazelton Research Products, Denver, PA) (complete media). Stock actinomycin$\mathrm{D}$ (Sigma) was prepared at a concentration of $5 \mathrm{mg} / \mathrm{ml}$ in dimethyl sulfoxide (DMSO) (Sigma).

\section{Isolation and Protocol for PBMC}

Peripheral blood was obtained by venipuncture from healthy human volunteers. Two hundred milliliters of heparainized (50 USP U/ml) whole blood (WB) was diluted 1:1 with sterile saline. PBMC from diluted WB were separated by density centrifugation on FicollHypaque (Pharmacia, Piscataway, NJ). Isolated mononuclear cells were resuspended in complete media and washed three times. Total cell counts and viability analyses using trypan blue exclusion were conducted and viability always exceeded $95 \%$. Five milliliters of PBMC $\left(4 \times 10^{6} \mathrm{cells} / \mathrm{ml}\right)$ was plated on $60 \mathrm{~mm}$ plastic culture plates (Costar, Cambridge, MA) or in $15 \mathrm{ml}$ Teflon chambers (Savillex Co., Minnetonka, MN) and incubated with or without specific reagents at $37^{\circ} \mathrm{C}$ in $95 \%$ air and $5 \% \mathrm{CO}_{2}$. Cells were incubated in either 8 well Lab-tek slides (Nunc, Inc., Naperville, IL) or in Teflon chambers for immunolocalization of IL-8 antigen. Cells and supernatants were harvested at specific time intervals for isolation of steady-state IL-8 mRNA, immunohistochemical analysis of IL-8 cell-associated antigen, or chemotactic bioactivity.

To ascertain the potential mechanism of adherenceinduced IL-8, PBMC were incubated with either cycloheximide $(10 \mu \mathrm{g} / \mathrm{ml})$, actinomycin-D $(5 \mu \mathrm{g} / \mathrm{ml})$, neutralizing monoclonal antihuman IL-1 $\beta$ antibodies $(75 \mu \mathrm{g} /$ $\mathrm{ml})$, control murine IgG $(75 \mu \mathrm{g} / \mathrm{ml})$, rabbit preimmune sera (1:100 dilution), or neutralizing rabbit antihuman TNF antibodies (1:100 dilution) for $8 \mathrm{~h}$. In experiments utilizing cycloheximide, PBMC suspensions were preincubated with cycloheximide in Teflon chambers for $1 \mathrm{~h}$ prior to transfer to plastic plates, whereas other reagents were added to cells concomitantly with exposure to plastic.

\section{Northern Blot Analysis}

Total RNA from PBMC was isolated using a modification of the method of Chirgwin et al. [3] and Jonas et al. [10]. Briefly, PBMC were lysed by a solution of $25 \mathrm{mM}$ tris, $\mathrm{pH} 8.0$, containing 4.2 $\mathrm{M}$ guanidine isothiocyanate, $0.5 \%$ N-Lauroylsarcosine (Sigma, St. Louis, $\mathrm{MO}$ ), and 0.1 M 2-mercaptoethanol. After homogenization, the above suspension was added to an equal volume of $100 \mathrm{mM}$ tris, $\mathrm{pH} 8.0$, containing $10 \mathrm{mM}$ EDTA and $1.0 \%$ sodium dodecyl sulfate. The mixture was then extracted with phenol-chloroform $(1: 1 ; \mathrm{vol} / \mathrm{vol})$ and chloroform-isoamyl alcohol $(24: 1 ; \mathrm{vol} / \mathrm{vol})$ and alcohol-precipitated. The pellet was dissolved in diethyl pyrocarbonate (DEPC)-treated $\mathrm{H}_{2} \mathrm{O}$. The RNA was separated by Northern blot analysis using formaldehyde, $1 \%$ agarose gels, and transblotted to nitrocellulose. The blots were baked, prehybridized, and hybridized with a ${ }^{32} \mathrm{P}-5^{\prime}$ end-labeled synthetic oligonucleotide probe for human IL-8. A 30-mer oligonucleotide probe was complementary to nucleotides 262-291 of the published cDNA and had the sequence 5-GTT-GGC-GCA-GTG-TGG-TCCACT-CTC-AAT-CAC-3', which failed to have significant overlap with other homologous cDNAs [11]. Blots were washed, and autoradiographs were quantitated using laser densitometry (Ultrascan XL, LXB Instruments, Inc.). Equivalent amounts of total RNA/gel were assessed by monitoring $28 \mathrm{~s}$ and 18s rRNA.

\section{Immunohistochemistry}

Immunolocalization of IL-8 was performed on adherent PBMC from Lab-tek slides or cytocentrifugation of nonadherent PBMC from Teflon chambers as previously described [18]. Briefly, cells were fixed in 4\% paraformaldehyde (Eastman Kodak Co.) in $1 \times$ phosphate buffered saline (PBS) for 10 min followed by rinsing twice in $1 \times$ PBS. Prior to staining, slides were fixed again for 15 min in $1: 1$ absolute methanol and $3 \% \mathrm{H}_{2} \mathrm{O}_{2}$, rinsed in $1 \times$ PBS, then nonspecific binding sites were blocked with 1:50 normal goat serum. Normal serum was removed, followed by the addition of 1:2,000 dilution of either control serum (rabbit) or rabbit antihuman IL-8 serum [19]. After $15 \mathrm{~min}$ of incubation at $37^{\circ} \mathrm{C}$, the slides were rinsed with $1 \times$ PBS, overlaid with biotinylated goat antirabbit IgG (1:200; Vector Laboratories), incubated $15 \mathrm{~min}$, and rinsed three times with $1 \times$ PBS. The slides were treated with streptavidin conjugated to peroxidase for $15 \mathrm{~min}$ at $37^{\circ} \mathrm{C}$, rinsed three times, overlaid 
with substrate chromogen (3-amino 9-ethyl carbazole) for $7 \mathrm{~min}$ at $37^{\circ} \mathrm{C}$ to allow color development, and rinsed with distilled $\mathrm{H}_{2} \mathrm{O}$. Mayer's hematoxylin was used as a counterstain. To demonstrate antibody specificity, immunostaining of human IL-8 showed $100 \%$ inhibition by the addition of excess exogenous recombinant IL-8. The results were expressed as a percent of positive IL-8 antigen expressing PBMCs as compared with the total number of PBMCs counted per high power field (HPF, $\times 400)$.

\section{Chemotaxis Bioassay}

Human neutrophils (>99\%) were prepared from peripheral blood by Ficoll-Hypaque density gradient centrifugation followed by sedimentation in 5\% dextran/ $0.9 \%$ saline (Sigma). Neutrophils were separated from erythrocytes by hypotonic lysis and then suspended in Hank's balanced salt solution (HBSS) with calcium/ magnesium (GIBCO) at $2 \times 10^{6}$ cells $/ \mathrm{ml}$, with greater than $95 \%$ viability by trypan blue exclusion. Chemotaxis was examined as previously described [21]. Briefly, $160 \mu$ l of diluted (1:1) supernatant specimen, $10^{-7} \mathrm{M}$ formylmethionyleucylphenylalanine (fMLP) (Sigma, St. Louis, MO), or HBSS alone was placed in duplicate bottom wells of a blind-well chemotaxis chamber. A $3 \mu \mathrm{m}$ pore size polycarbonate filter (polyvinylpyrrolidone-free: Nuclpore Corp.) was placed in the assembly, and $250 \mu \mathrm{l}$ of neutrophil suspension placed in each of the top wells. Chemotaxis chamber assemblies were incubated at $37^{\circ} \mathrm{C}$ in humidified $95 \%$ air and $5 \% \mathrm{CO}_{2}$ for $1 \mathrm{~h}$, and the filters were removed, fixed in methanol, and stained with $2 \%$ toluidine blue (Sigma). Neutrophils that had migrated through to the bottom of the filter were counted in 10 HPF $(\times 1,000)$. Chemotactic bioactivity was expressed as the mean number of cells per HPF $(\times 1,000)$. In neutralization experiments, PBMC conditioned media (CM) from either adherence (plastic) or nonadherence (Teflon) were treated with a 1:1,000 dilution of either control (rabbit preimmune serum) or neutralizing rabbit antihuman IL-8 antiserum and assayed for chemotactic activity.

\section{IL-8 ELISA}

Antigenic IL-8 was quantitated using a double ligand enzyme-linked immunosorbent assay (ELISA) method, as previously described [18]. Briefly, flat-bottomed 96 well microtiter plates (Nunc Immuno-Plate I 96-F) were coated with goat anti-IL-8 antibody $(9.5 \mu \mathrm{g}$ in $100 \mu \mathrm{l}$ $0.1 \mathrm{M} \mathrm{NaHCO}_{3}, \mathrm{pH} 9.6$ ) for $16 \mathrm{~h}$ at $4^{\circ} \mathrm{C}$ and then washed with PBS, pH 7.5/0.5\% Tween 20 (washing buffer). Microtiter plate nonspecific binding sites were blocked with bovine serum albumin (BSA) in washing buffer and incubated for $1 \mathrm{~h}$ at $37^{\circ} \mathrm{C}$. Plates were twice rinsed with washing buffer and diluted samples $(100 \mu \mathrm{l})$ in duplicate were followed by incubation for $90 \mathrm{~min}$ at $37^{\circ} \mathrm{C}$. Plates were washed twice, biotinylated goat anti-IL-8 (final concentration 1:2,000) was added, and plates were incubated for $90 \mathrm{~min}$ at $37^{\circ} \mathrm{C}$. Plates were washed twice again, and streptavidin-peroxidase conjugate added and incubated for $30 \mathrm{~min}$ at $37^{\circ} \mathrm{C}$. Plates were washed twice and chromogen substrate added. The plates were incubated at room temperature to the desired extinction, and the reaction terminated with $3 \%$ oxalic acid solution. Plates were read at $405 \mathrm{~nm}$ in an ELISA reader. Standards were $1 / 2 \log$ dilutions of recombinant IL-8, from $100 \mathrm{ng}-0.3 \mathrm{ng} /$ well. This ELISA method consistently detected IL-8 concentrations above $30 \mathrm{pg} / \mathrm{ml}$.

\section{Statistical Analysis}

Data were analyzed by Macintosh II computer using Statview II statistical package (Abacus Concepts, Inc.). Data are expressed as means \pm SEM. Data that appeared statistically significant were compared by Student's $t$-test for comparing the means of multiple groups, and considered significant if $P<0.05$.

\section{RESULTS \\ Adherent Mononuclear Cell-Derived Gene Expression for IL-8}

Initial studies were performed in order to assess IL-8 gene expression by adherent vs. nonadherent PBMC. Adherent cells were cultured on plastic plates, while nonadherent PBMC were cultured in Teflon chambers $(n=3)$. The total cellular RNA was isolated and extracted in a time-dependent fashion. Kinetic analysis of steady-state IL-8 mRNA levels was determined from $2 \times 10^{7}$ cells at $0,0.5,1,2,4,8$, and $24 \mathrm{~h}$. Depicted in Figure 1 is a representative Northern blot analysis showing adherent PBMC-derived IL-8 steady-state mRNA that was apparent by $30 \mathrm{~min}$, peaked at $8 \mathrm{~h}$, and then declined over the next $16 \mathrm{~h}$. Similar findings were demonstrated in the other two autoradiographs with negligible differences between steady-state levels of IL-8 mRNA at either 2 or $4 \mathrm{~h}$ (data not shown). In contrast, nonadherent PBMC-derived IL-8 steady-state mRNA levels were not apparent until 4-8 h, and levels were less than $25 \%$ of maximal response seen with adherence.

\section{Immunohistochemical Localization of IL-8}

To establish whether PBMC-derived antigenic IL-8 was expressed, immunohistochemical localization of IL-8 antigen was performed from adherent vs. nonadherent PBMC populations in a time-dependent fashion $(n=3)$. Adherent or nonadherent PBMCs were cultured and fixed at $0,0.5,1,2,4,8$, or $24 \mathrm{~h}$. In immunohistochemical analyses, PBMC expressing IL- 8 antigen had monocyte morphology and nonspecific esterase staining. As shown in Figure 2, adherent as compared with nonadherent PBMC were expressing significant IL- 8 by 
A

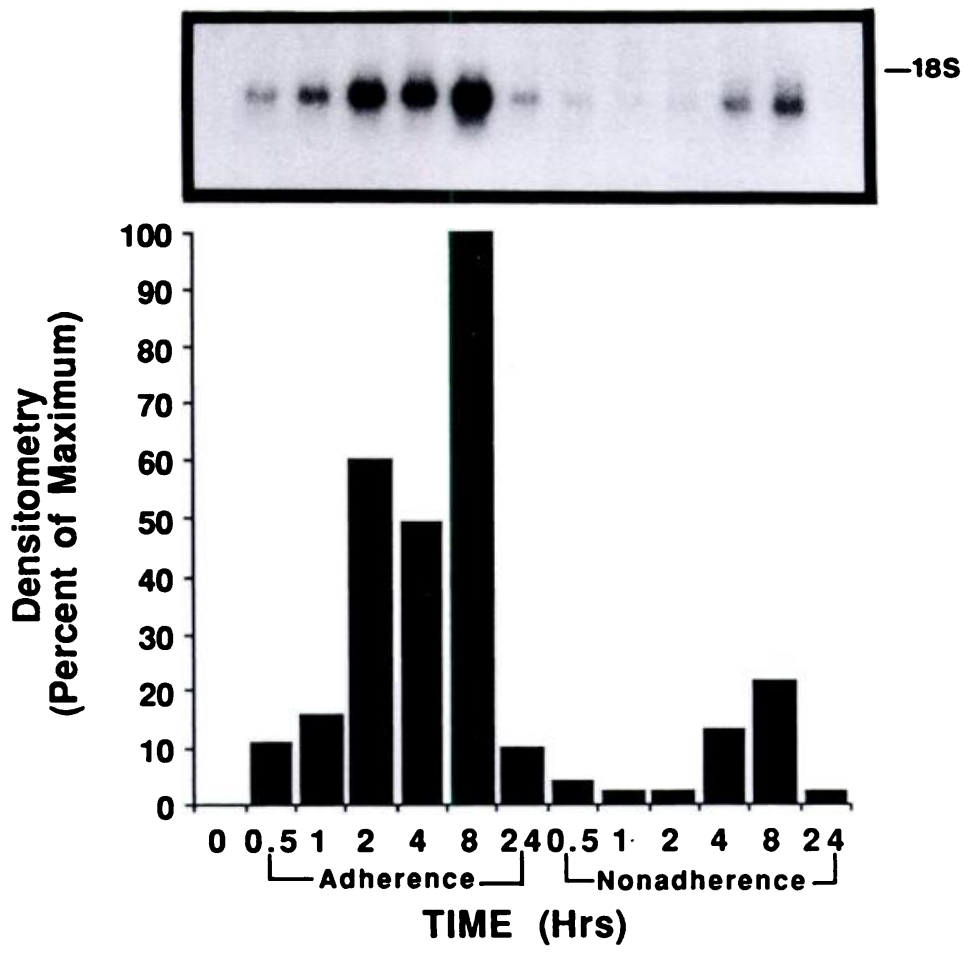

C

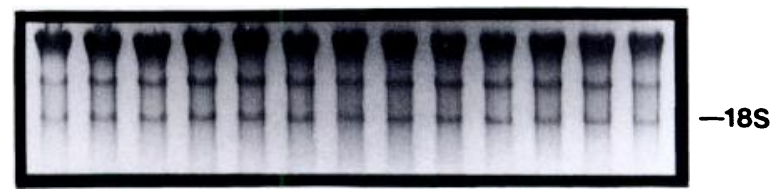

Fig. 1. Northern blot analysis of the kinetic expression of adherent vs. nonadherent PBMC IL-8 steady-state mRNA levels. A: Northern blot of specific IL-8 mRNA. B: Densitometry of the representative Northern blot. C: 185 rRNA from the above Northern blot, demonstrating equivalent amounts of total RNA loaded per lane. These data are representative of one of three experiments.

$2 \mathrm{~h}(P=0.01)$ and the difference in IL-8 antigenic expression between adherent and nonadherent PBMC remained significant $(P=0.001)$ at $8 \mathrm{~h}$, with $66.9 \pm 6.0 \%$ of the adherent PBMC expressing IL-8 antigen. By $24 \mathrm{~h}$, adherent PBMC-derived IL-8 antigenic expression was present in $71.9 \pm 5.5 \%$ of PBMCs. In contrast, nonadherent PBMC-derived IL-8 antigenic expression was not present until after $4 \mathrm{~h}$, and was less than $20 \%$ of the maximal IL-8 antigenic reactivity induced by adherent PBMC by $24 \mathrm{~h}(P=0.0001)$.

\section{PBMC-Derived Neutrophil Chemotactic Activity}

The observations of adherence-induced antigenic IL-8 from PBMC led to subsequent studies to determine if this antigenic IL-8 expression was associated with extracellular chemotactic bioactivity. Adherent and nonadherent PBMC were either cultured on plastic plates or in Teflon chambers, respectively. At specific time intervals $(0$,
$0.5,1,2,4,8$, and $24 \mathrm{~h})$, supernatants were harvested and assessed for PMN chemotactic bioactivity $(n=3)$. As depicted in Figure 3, adherent and nonadherent PBMC-derived chemotactic bioactivity was first apparent by $1-2 \mathrm{~h}$, but no significant difference in neutrophil chemotactic bioactivity existed until $8 \mathrm{~h}$. Adherent PBMC by $8 \mathrm{~h}$ were producing significantly more chemotactic activity $(P=0.03)$ as compared with nonadherent cells. Chemotactic bioactivity from nonadherent PBMC by $24 \mathrm{~h}$ was less than $40 \%$ of maximal chemotactic bioactivity generated by adherent PBMC $(P=0.02)$, and paralleled the results seen with immunolocalization of antigenic IL-8 from these two PBMC populations. To establish the definitive portion of chemotactic activity generated from adherent vs. nonadherent PBMC that was attributable to IL-8, neutralization studies were performed. As shown in Table 1, CM was obtained from adherent and nonadherent PBMC at $24 \mathrm{~h}$ and preincu- 


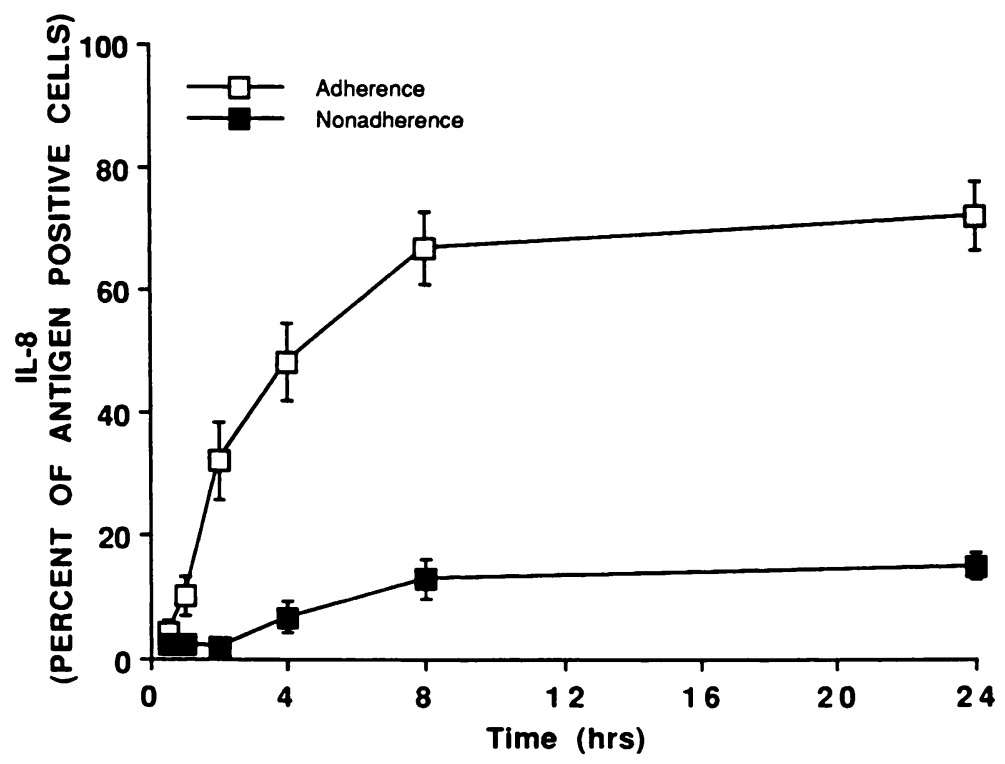

Fig. 2. Immunohistochemical analysis of cell-associated IL-8 antigen expression in a timedependent manner from adherent vs. nonadherent PBMC. The results were expressed as a percent of positive IL-8 antigen expressing PBMC as compared with the total number of PBMC counter per HPF $(\times 400)$. These data are representative of three experiments.



Fig. 3. PBMC-derived neutrophil chemotactic activity. PBMC $\left(4 \times 10^{6} / \mathrm{ml}\right)$ were cultured in plastic plates or Teflon chambers. At specific time intervals, supernatants were harvested and assessed for PMN chemotactic bioactivity. Chemotactic activity is expressed on the vertical axis as the mean number of cells per HPF $(\times 1,000)$. These data are representative of three experiments.

bated with either 1:1,000 dilution of control serum (preimmune) or rabbit antihuman IL-8 neutralizing antiserum. After incubation with sera, CM were analyzed for chemotactic bioactivity. Specific neutralizing effect of IL-8 antiserum showed a $29 \%$ reduction $(P=0.01)$ in neutrophil chemotactic activity from adherent PBMC. In addition, our neutralizing anti-IL-8 antibody failed to inhibit the chemotactic activity induced by fMLP $\left(10^{-7} \mathrm{M}\right)$.

\section{PBMC-Derived Antigenic IL-8 Expression}

We assessed the production of extracellular antigenic IL-8 expression by ELISA. Adherent and nonadherent PBMC were either cultured on plastic plates or in Teflon chambers, respectively, and at specific time intervals $(0$, $0.5,1,2,4,8$, and $24 \mathrm{~h}$ ) supernatants were harvested in the same way as PMN chemotactic bioassay. Extracellular antigenic IL-8 expression was determined utilizing a specific ELISA for IL-8. As shown in Figure 4, adherent PBMC-derived antigenic IL-8 was first apparent by $4 \mathrm{~h}$ and continued to increase over the next $20 \mathrm{~h}$. Adherent PBMC-derived antigenic IL-8 at $4 \mathrm{~h}$, $0.44 \pm 0.08 \mathrm{ng} / \mathrm{ml} \quad(P=0.05), 8 \mathrm{~h}, 1.4 \pm 0.1 \mathrm{ng} / \mathrm{ml}$ $(P=0.004)$, and $24 \mathrm{~h}, 3.0 \pm 0.8 \mathrm{ng} / \mathrm{ml}(P=0.04)$ was significantly greater than nonadherent PBMC-derived antigenic IL-8 at similar time-points. Antigenic IL-8 from nonadherent PBMC was detected at 8 and $24 \mathrm{~h}$, but was less than $20 \%$ of maximal antigenic IL-8 generated by adherent PBMC. These kinetics were similar to the results of immunolocalization of antigenic IL-8 and chemotactic activity from the supernatants of adherent and nonadherent PBMC.

\section{Actinomycin-D Inhibited Adherent PBMC IL-8 mRNA Expression}

It was apparent from the above observations that adherence to plastic resulted in induction of IL-8 mRNA 
TABLE 1. Neutralization of IL-8 Activity With Polyclonal Rabbit Antihuman IL-8 Antibody"

\begin{tabular}{|c|c|c|c|c|}
\hline & \multicolumn{4}{|c|}{ Mean number of cells per HPF $(\times 1,000)$} \\
\hline & $\begin{array}{c}\text { Control serum } \\
(1: 1,000)\end{array}$ & $\begin{array}{c}\text { Immune serum } \\
(1: 1,000)\end{array}$ & \% Suppression & $P$ value \\
\hline $\begin{array}{l}24 \mathrm{~h} \text { adherence } \\
\text { to plastic }\end{array}$ & $22.2 \pm 1.8$ & $15.8 \pm 0.6$ & 29 & 0.01 \\
\hline $\begin{array}{l}24 \mathrm{~h} \text { nonadherence } \\
\text { in Teflon }\end{array}$ & $15.5 \pm 0.8$ & $16.4 \pm 0.4$ & $\mathrm{NC}^{*}$ & 0.12 \\
\hline fMLP $10^{-7} \mathrm{M}$ & $82.7 \pm 0.9$ & $81.9 \pm 9.7$ & NC* & 0.48 \\
\hline
\end{tabular}

adherent and nonadherent PBMC-derived supernatants $(n=3)$ were isolated after $24 \mathrm{~h}$, collected, and incubated with control or immune serum for $30 \mathrm{~min}$ at $37^{\circ} \mathrm{C}$ before chemotaxis analysis.

*NC, no significant change.



Fig. 4. PBMC-derived extracellular antigenic IL-8. PBMC $\left(4 \times 10^{6} / \mathrm{ml}\right)$ were cultured. At specific time intervals, supernatants were harvested and assessed for antigenic IL-8 by a specific ELISA. IL-8 ELISA data are expressed on the vertical axis as $\mathrm{ng} / \mathrm{ml}$. These data are representative of three experiments.

steady-state levels with subsequent translation to cellassociated IL-8 antigen that was paralleled by extracellular bioactivity. To establish whether this IL-8 mRNA expression was induced at the level of gene transcription or secondary to stabilization of constitutive IL-8 mRNA, we next treated adherent PBMC concomitantly with actinomycin-D. PBMCs were cultured in the presence or absence of actinomycin-D $(5 \mu \mathrm{g} / \mathrm{ml})$ on plastic for $8 \mathrm{~h}$. As shown in Figure 5, adherent PBMC-derived IL-8 mRNA in the presence of actinomycin-D was less than $5 \%$ of the steady-state mRNA levels in the absence of actinomycin-D. These findings indicated that PBMCderived IL- 8 mRNA was induced de novo upon adherence to plastic.

\section{Adherence-Induced PBMC-Derived IL-8 Gene Expression Is Protein Dependent}

To determine whether the observed adherence-induced PBMC-derived IL-8 gene expression was protein mediated, we next pretreated PBMC in the presence or absence of cycloheximide $(10 \mu \mathrm{g} / \mathrm{ml})$ for $1 \mathrm{~h}$ in Teflon chambers prior to plastic exposure. PBMC were cultured on plastic plates for $8 \mathrm{~h}$ and total RNA isolated. After $8 \mathrm{~h}$ culture, the PBMC were greater than $90 \%$ viable. In the presence of cycloheximide, adherence-induced PBMCderived IL-8 mRNA was less than $50 \%$ of the steady-state levels seen in the absence of cycloheximide (Fig. 6). These results supported the notion that de novo protein 
A

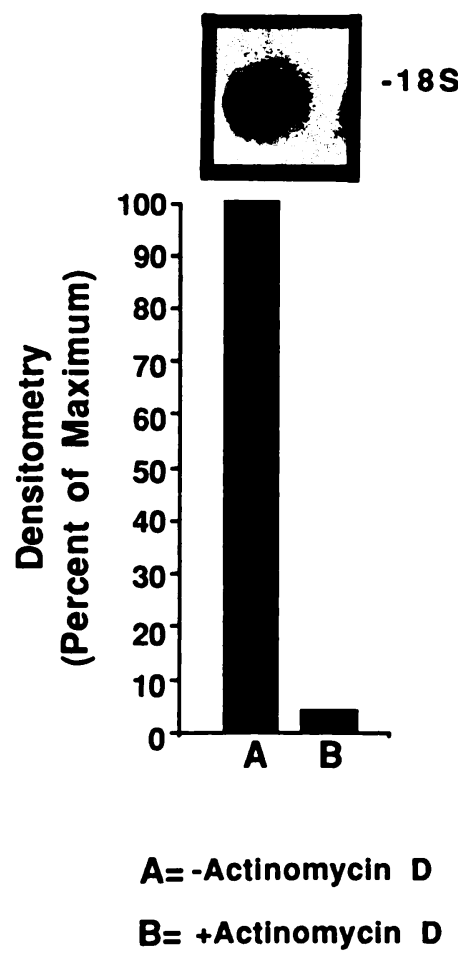

Fig. 5. Northern blot analysis of IL-8 mRNA from PBMC incubated on plastic plates for $8 \mathrm{~h}$. PBMC were treated with or without actinomycin-D $(5 \mu \mathrm{g} / \mathrm{ml})$. A: Northern blot of specific IL-8 mRNA. B: Densitometry of the representative Northern blot. These data are representative of one of three experiments.

synthesis is necessary for adherence-induced PBMCderived IL-8 gene expression. Furthermore, to exclude the participation of either adherence-induced PBMCderived IL-1 or TNF as endogenous stimuli for the expression of PBMC-derived IL-8, we concomitantly cultured PBMC in the presence of either murine IgG $(75 \mu \mathrm{g} / \mathrm{ml})$, neutralizing monoclonal IL-1 $\beta$ antibodies $(75 \mu \mathrm{g} / \mathrm{ml})$, preimmune rabbit sera $(1: 100)$, or neutralizing rabbit anti-TNF antibodies (1:100). PBMC were cultured for $8 \mathrm{~h}$ on plastic and total RNA isolated. Neither IL-1 $\beta$ nor TNF neutralizing antibodies altered adherence-induced IL-8 steady-state mRNA levels (data not shown).

\section{DISCUSSION}

Inflammatory cell adherence to microvascular endothelium is the initial event in the process of leukocyte migration from the vascular space to sites of inflammation $[2,5,6,9,13,23]$. This event was previously thought to be passive and only associated with leukocyte-toendothelium adherence. Recent investigations have now demonstrated that adherence to either plastic, endothelial cells, or matrix constituents is a potent stimulus for gene
A
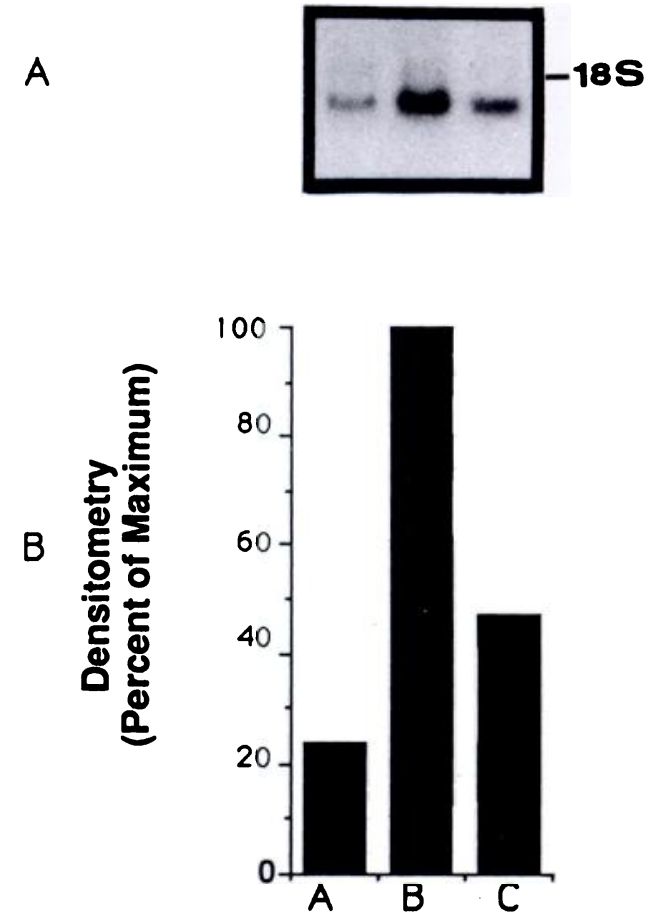

$$
\begin{aligned}
& A=\text { Tefion alone } \\
& B=\text { Plastic }- \text { Cycloheximide } \\
& C=\text { Plastic +Cycloheximide }
\end{aligned}
$$

C

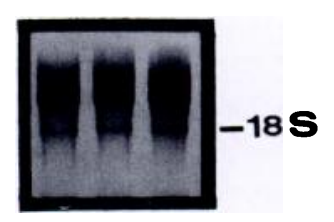

Fig. 6. Northern blot analysis of IL-8 mRNA by PBMC Incubated on plastic plates or in Tefion chambers for $8 \mathrm{~h}$. PBMC were preincubated with or without cycloheximide $(10 \mu \mathrm{g} / \mathrm{ml})$. A: Northern blot of specific IL-8 mRNA. B: Densitometry of the representative Northern blot. C: 185 rRNA from the above Northern blot, demonstrating equivalent amounts of total RNA loaded per lane. These data are representative of one of three experiments.

expression of several inflammatory cytokines, incuding IL-1 $\alpha$, IL-1 $\beta$, TNF, and CSF-1 $[4,8,15]$. These inducible inflammatory cytokines have pleiotropic effects on an array of immune and nonimmune cells that are critical for the mediation of inflammation.

The influx of PMN is preeminent in acute inflammation and likely dependent upon the formation of chemotactic gradients. The mechanism(s) by which PMN are recruited remain to be fully elucidated. Although TNF and IL-1 were originally identified as neutrophil chemoattractants, recent studies have shown this activity is not direct. Through the purification and cloning of the 
chemotactic and activating polypeptide IL-8, it is apparent that IL-1 and TNF may mediate significant PMN chemotaxis through the induction of this novel chemotactic cytokine [11].

IL-8 has been referred to as monocyte-derived neutrophil chemotactic factor (MDNCF) [11], neutrophil attractant/activating peptide-1 (NAP-1) [1], neutrophil chemotactic factor (NCF) [20-22], and most recently IL-8 [1]. The active form of IL-8 is a 72 amino acid peptide with an estimated MW of 8,000 daltons, and belongs to a unique supergene family that includes murine macrophage inflammatory peptide-2, platelet factor 4, human platelet basic protein, human inducible protein IP-10, 9E3/pCEF-4 from Rous sarcoma transformed fibroblasts, and melanoma growth-stimulatory activity (GRO/MGSA) [25]. Monocytes and macrophages appear to be the predominant sources of IL-8, although endothelial cells, fibroblasts, and synovial cells have also been shown to generate IL-8 [20-22,24]. IL-8 has a relatively long half-life and is somewhat resistant to proteolytic enzymatic cleavage as compared with other chemotactic factors, suggesting that this cytokine may be involved in more prolonged inflammatory cell influx or may have biological functions in addition to neutrophil chemotaxis and activation.

In this study we extend these observations to include adherence to plastic as an important stimulus for the induction of IL-8 from PBMC. We have demonstrated the adherence-induced PBMC-derived gene expression of IL-8 by Northern blot analysis, the presence of antigenic cell-associated IL-8 protein by immunohistochemistry, IL-8 ELISA, and the production of chemotactic bioactivity attributable to IL-8. IL-8 gene and antigenic expression, together with bioactivity was timedependent, with steady-state IL-8 mRNA and protein peaking at 8 and $24 \mathrm{~h}$, respectively. Moreover, actinomycin-D treatment revealed that adherence-induction of steady-state IL-8 mRNA was de novo, whereas cycloheximide pretreatment demonstrated a protein intermediate was required for adherence-induced stimulation of steady-state IL-8 mRNA. Adherence-induced IL-8 did not appear to be mediated by either PBMC-derived IL-1 $\beta$ or TNF, as specific neutralizing antibodies for these cytokines failed to alter adherence-induced IL-8 gene expression. Therefore, adherence-induced IL-8 from PBMC reflects de novo production and was dependent upon a protein intermediate that was neither IL-1 nor TNF. Continuing investigations are underway to delineate the specific proteins that are required to mediate this adherence-induced IL-8 generation.

Although histologically PMN are predominant in acute inflammation, monocytes may be equally important since radiolabeled monocytes arrive early during the initiation of acute inflammation [9]. These observations suggest that as monocytes become adherent to the endothelium during the evolution of an inflammatory reaction, they can become activated and release cytokines such as IL-1, TNF, and IL-8. IL-1 and TNF can act in an autocrine or paracrine fashion to elaborate additional IL-8 from surrounding immune and nonimmune cells [20-22,24] amplifying the elicitation of additional PMN from the vascular compartment into the extravascular space.

\section{ACKNOWLEDGMENTS}

This research was supported in part by an American Lung Association Grant and National Institutes of Health grants HL02401, HL31693, HL35276, and DK38149. Dr. Strieter is an RJR Nabisco Research Scholar.

\section{REFERENCES}

1. Baggiolini, M., Walz, A., and Kunkel, S.L. Neutrophil-activating peptide-1/interleukin-8, a novel cytokine that activates neutrophils. J. Clin. Invest. 84,1045, 1989.

2. Bevilaqua, M.P., Pober, J.S., Wheeler, M.E., Cotran, R.S., and Gimbrone, M.A. Interleukin-1 acts on cultured vascular endothelium to increase the adhesion of polymorphonuclear leukocytes, monocytes, and related leukocyte cell lines. J. Clin. Invest. $76,2003,1985$.

3. Chirgwin, J.M., Przybyca, A.E., MacDonald, R.J., and Rutter, W.J. Isolation of biologically active ribonucleic acid from sources enriched ribonuclease. Biochemistry 18,5294, 1978.

4. Eierman, D.F., Johnson, C.E., and Haskill, J.S. Human monocyte inflammatory mediator gene expression is selectively regulated by adherence substrates. J. Immunol. 142,1970, 1989.

5. DiCorleto, P.E., and de la Motte, C.A. Characterization of the adhesion of the human monocytic cell line U937 to cultured endothelial cells. J. Clin. Invest. 75,1153, 1985.

6. Doherty, D.E., Haslette, C., Tonnesen, M.G., and Henson, P.M. Human monocyte adherence: a primary effect of chemotactic factors on the monocyte to stimulate adherence to human endothelium. J. Immunol. 138,1762, 1987.

7. Fels, A.D.S., and Cohn, Z.A. The alveolar macrophage. J. Appl. Physiol. 60,353, 1986.

8. Haskill, S., Johnson, C., Eierman, D., Becker, S., and Warren, $K$. Adherence induces selective mRNA expression of monocyte mediators and proto-oncogenes. J. Immunol. 140,1690, 1988.

9. Issekutz, T.B., Issekutz, A.C., and Movat, H.Z. The in vivo quantitation and kinetics of monocyte migration into acute inflammatory tissue. Am. J. Pathol. 103,47, 1981.

10. Jonas, E., Sargent, T.D., and Davis, I.B. Epidermal keratin-gene expressed in embryos of Xenopus laevis. Proc. Natl. Acad. Sci. U.S.A. 82,5413, 1985.

11. Matsushima, K., Morishita, K., Yoshimura, T., Lavu, S., Kobayashi, Y., Lew, W., Appella, E., Kung, H.F., Leonard, E.J., and Oppenheim, J.J. Molecular cloning of a human monocyte-derived neutrophil chemotactic factor (MDNCF) and the induction of MDNCF mRNA by interleukin- 1 and tumor necrosis factor. J. Exp. Med. 167,1883, 1988.

12. Nathan, C.F. Secretory products of macrophages. J. Clin. Invest. 79,319, 1987.

13. Pawlowski, N.A., Abraham, E.L., Pointer, S., Scott, W.A., and Cohn, Z.A. Human monocyte endothelial cell interaction in vitro. Proc. Natl. Acad. Sci. U.S.A. 82,8208, 1985.

14. Peveri, P., Walz, A., Dewald, B., and Baggiolini, M. A novel neutrophil-activating factor produced by human mononuclear phagocytes. J. Exp. Med. 167,1547, 1988. 
15. Fuhlbrigge, R.C., Chaplin, D.D., Kiely, J.M., and Unanue, E.R. Regulation of interleukin 1 gene expression by adherence and lipopolysaccharide. J. Immunol. 138,3799, 1987.

16. Samuelsson, B. Leukotrienes; mediators of immediate hypersensitivity reactions and inflammation. Science 220,568, 1983.

17. Showell, H.J., Freer, R.J., and Zigmond, S.H. Structure-activity relations of synthetic peptides as chemotactic factors and inducers of lysosomal enzyme secretion for neutrophils. J. Exp. Med. $143,1154,1976$.

18. Standiford, T.J., Strieter, R.M., Chensue, S.W., Westwick, J., Kasahara K., and Kunkel, S.L. IL-4 inhibits the expression of IL-8 from stimulated human monocytes. J. Immunol. 145,1435, 1990.

19. Strieter, R.M., Chensue, S.W., Basha, M.A., Standiford, T.J., Lynch III, J.P., Baggiolini, M., and Kunkel, S.L. Human alveolar macrophage gene expression of interleukin- 8 by tumor necrosis factor- $\alpha$, lipopolysaccharide, and interleukin-1 $\beta$. Am. J. Respir. Cell Mol. Biol. 2,321, 1990.

20. Strieter, R.M., Kunkel, S.L., Showell, H.J., and Marks, P.M. Monokine-induced gene expression of a human endothelial cellderived neutrophil chemotactic factor. Biochem. Biophys. Res. Commun. 156,1340, 1988.

21. Strieter, R.M., Kunkel, S.L., Showell, H.J., Remick, D.G.,
Phan, S.H., Ward, P.A., and Marks, R.M. Endothelial cell gene expression of a neutrophil chemotactic factor by TNF- $\alpha$, LPS, and IL-1 $\beta$. Science 243,1467, 1989.

22. Strieter, R.M., Phan, S.H., Showell, H.J., Remick, D.G., Lynch, J.P., Genord, M., Raiford, C., Eskandari, M., Marks, R.M., and Kunkel, S.L. Monokine-induced neutrophil chemotactic factor gene expression in human fibroblasts. J. Biol. Chem. 264,10621, 1989.

23. Wallis, W.J., Beatty, P.G., Ochs, H.D., and Harlan, J.M. Human monocyte adherence to cultured vascular endothelium; monoclonal antibody-defined mechanisms. J. Immunol. 135, 2323, 1985.

24. Watson, M.L., Lewis, G.P., and Westwick, J. Neutrophil stimulation by recombinant cytokines and a factor produced by IL-1-treated synovial cell culture. Immunology 65,567, 1988.

25. Wolpe, S.D., and Cerami, A. Macrophage inflammatory proteins 1 and 2: members of a novel superfamily of cytokines. FASEB J. $3,2565,1989$.

26. Yoshimura, T., Matsushima, K., Oppenheim, J.J., and Leonard, E.J. Neutrophil chemotactic factor produced by lipopolysaccharide (LPS)-stimulated human blood mononuclear leukocytes: partial characterization and separation from interleukin-1 (IL-1). J. Immunol. 139,788, 1987. 